\title{
On the presence of Daphnia galeata in Lake Orta (N. Italy)
}

\author{
Roberta PISCIA*, Jaromir SEDA ${ }^{1)}$, Carla BONACINA and Marina MANCA \\ CNR Institute of Ecosystem Study, Largo Tonolli 50, 28922, Verbania, Italy \\ ${ }^{1)}$ Biology Centre of the ASCR, Hydrobiological Institute, Na sádkách 7 České Budějovice, 370 05, Czech Republic \\ *e-mail corresponding author: r.piscia@ise.cnr.it
}

\begin{abstract}
Lake Orta is a very interesting environment because of its history of heavy chronic pollution and biota re-colonization. It was the first deep lake in Italy in which allozyme techniques were used to investigate clonal diversity. In 1986, a newly established Daphnia obtusa population, able to colonize stressed environments, resulted composed by just one multilocus genotype, detected through an analysis of 27 different allozymes, fifteen of which active and stable for up to 12 generations. This result was interpreted as indicative of a colonization by a single clone, able to establish after a strong selection. This species was allochthonous for the lake, and in 1996 was replaced by a Daphnia longispina of the same morphotype as that originally described from its pelagic environment, the latter apparently remaining the only Daphnia species also in the lake's littoral until 2001, i.e. until a regular sampling to monitor the lake was accomplished. During an accidental sampling in 2004, for detecting the occurrence and prevalence of parasites in Daphnia parental species and hybrids in several lakes located North and South of the Alps, Daphnia galeata was first found in Lake Orta's pelagic environment, as revealed by morphological and allozyme analyses. Lake Orta zooplankton was then resampled in June 2006, to detect species as well as clonal composition of the Daphnia population, using the same techniques of morphotype and allozyme analyses. We expected to find low clone diversity and the occurrence of hybrids, whose success is enhanced in disturbed environments. Although preliminary, our results confirm that clone diversity Lake Orta's Daphnia population is low, thus suggesting a recent colonization by $\mathrm{D}$. galeata and providing evidence for a founder effect. In addition, the detection of the $M$ variant at the AO locus, we interpret as a rare allele of $\mathrm{D}$. galeata/D. longispina hybrids, perfectly fits the hypothesis of an enhancement of hybrid success in disturbed environments such as the once heavy polluted Lake Orta.
\end{abstract}

Key words: pollution, recolonization, D. longispina, D. galeata allozymes, clones, founder effect

\section{INTRODUCTION}

\subsection{Lake Orta an elective site for studies on pollution and re-colonization}

Lake Orta is an unique site for its history of pollution, recovery and re-colonization. Zooplankton, particularly Daphnia, has been the object of long-term investigations, which allowed for tracing the appearance, success and decline of different species. Because of its peculiar history and the need to investigate the recolonization at high definition level (i.e. molecular, Bachiorri et al. 1989; Bachiorri et al. 1991), Lake Orta has been the first site in Italy in which a classic morphological analysis was combined with that of allozyme markers. These studies provided information on the genetic structure of the Daphnia population responsible for the biota re-colonization during a gradual recovery from pollution. As expected, the allochtonous Daphnia obtusa population detected in the lake in 1986 was genetically homogeneous, probably as the result of a successful hatching of resting eggs produced by one resistant clone, able to survive under strong selective conditions, such as those imposed by a situation of heavy pollution (Bachiorri et al. 1991; Bonacina et al. 1994).

Lake Orta case study has been a unique example of a founder effect in such a large lake and provided an important occasion for discussing patterns and mechanisms of recovery and re-colonization of the pelagic environment. For this reason, the occasional finding of Daphnia galeata stimulated the present preliminary study, aimed at detecting, in addition to the presence of the species, the genetic structure of its population, as well as the occurrence of hybrids, the latter expected because of the high level of disturbance of this environment.

\subsection{The study site and its history of pollution, recovery and biota re-colonization}

Located in Northern Italy, Lake Orta is the seventh largest Italian lake by volume. Before pollution, the zooplankton population (Pavesi 1879; Monti 1930) was composed by seven species of cladocerans, five of copepods and several rotifers. Already poorly buffered (total alkalinity ranging between 0.3-0.4 meq ${ }^{-1}$; Monti 1929) because of the geology of the catchment basin, it was acidified after heavy industrial pollution starting from 1926 (Bonacina 2001). The pollution stopped in 1980 , four years after the approval by the Italian Parliament of a law on the regulation of the discharge of industrial wastes into freshwater environments. The lake reaction was fast (Bonacina et al. 1986; Mosello et al. 1986; Bonacina et al. 1988a, 1988b; Calderoni et al. 1990a), further accelerated after a liming intervention in 1989-1990 (Calderoni et al. 1990b, 1991, 1992). 
Zooplankton promptly reacted to the initial signals of recovery: after the rotifers, the allochtonous Daphnia obtusa, a species able to live in stressed environments (Fryer 1985), colonized the lake. A combined analyses of morphological and genetic diversity (Bachiorri et al. 1991) suggested that the population was established by a single clone, able to exploit the peculiar environmental conditions, which imposed a strong selection (Bonacina et al. 1994).

Strong interannual and seasonal population density fluctuations were recorded until 1996, when D. obtusa disappeared from the pelagic community, being replaced by a Daphnia longispina of the same morphotype as that found before the lake pollution (mainly identified by the absence of a dorsal head crest: Margaritora 1983; Flößner 2000; Benzie 2005).

The latter was recorded until 2001 (Signorini 2006), i.e. until when a regular monitoring of the lake zooplankton was carried on, also allowing for detecting an increasing complexity of the community along with the reduction in dissolved ammonia concentration.

In 2004, we accidentally collected live zooplankton samples, as Lake Orta was one of the 28 lakes in Italy in which a project on Daphnia parasites was carried out in cooperation with EAWAG, Dübendorf (Wolinska et al. 2007). The aim of the study was to identify and study parasite infection in parental and hybrids of the $D$. longispina group in lakes of different size and trophic history, located North and South of the Alps. The occurrence and dominance of hybrids, together with changes in lake trophy were analyzed (Keller et al. 2006). The results of this study, based on allozymes, indicated the presence of Daphnia galeata in the lake. A monitoring of Lake Orta zooplankton started again in June 2006. As D. galeata was still present in the pelagic zone of the lake, we also collected a live sample for allozyme analyses to investigate species, as well as clone diversity. Being Lake Orta's Daphnia populations cyclical parthenogens, we expected hybridization between the two most recently established species to have occurred, thus further complicating the interpretation of classic morphological analyses. In the present paper we report the results of this preliminary study.

\subsection{Classic diagnostic traits and the allozyme analysis}

Daphnia of the longispina group, to which both $D$. galeata (Sars) and D. longispina (O. F. Müller) belong, are the most common species inhabiting large European permanent water bodies (lakes and reservoirs). Their ubiquitous presence is attributed to their ability to cope with fish predation better than Daphnia of the pulex group (Hrbáček 1987), which tend to be confined to the littoral of deep lakes or to those with low fish predation pressure. The species of the D. longispina group are characterized by a high phenotypic plasticity, their highly variable morphology being strongly influenced by lake environmental conditions.
An important morphological trait for the differential diagnosis of $D$. longispina with respect to the other species of the group is the presence of a head smoothly round and with outline falling down just behind the eye, not pointed or spined, or extended into a helmet (Margaritora 1983; Flößner 2000; Benzie 2005). In addition to this relatively simple and well established criterion, other morphological traits, based on quantitative morphological features (i.e. aesthetes, ocellus, eye position and postabdominal processes) have been more recently established, which show a large variability (Petrusek et al. 2005), thus making the diagnosis very difficult at present. The problem of reliable taxonomical identification is further complicated by the fact that interspecific hybridisation seems to be a common phenomenon.

The occurrence of hybrids was reported from many lakes and ponds (e.g. Wolf \& Mort 1986; Hebert et al. 1989; Schwenk \& Spaak 1995; Spaak 1996) and interspecific hybrids were generated in laboratory crossing experiments (Schwenk et al. 2001). Despite potential introgression, parental species remain genetically distinct, since interspecific hybrids show in most cases a lower hatching and survival rate than parental species, i.e. hybrid breakdown (Schwenk et al. 2001). Some transient morphological forms from field samples often result from a combination of great morphological plasticity and hybridization, and therefore, molecular techniques, among which the allozyme analysis, represent an useful tool for taxonomy of field populations.

\section{METHODS}

Two zooplankton samples were collected in June 2006 at the station corresponding to the maximum depth of the lake $(143 \mathrm{~m})$ with a Clarke-Bumpus plankton sampler equipped with a $76 \mu \mathrm{m}$ nylon net exploring a layer from surface to $50 \mathrm{~m}$. One sample was immediately fixed in $90 \%$ denaturated ethanol and then transferred into a $10 \%$ formaldehyde. The other one was used to randomly select 50 live Daphnia, which were kept frozen in liquid nitrogen until allozyme analyses were performed. We used electrophoresis on acetate cellulose gels (Hebert \& Beaton 1989), using tris-Glycine buffer at $\mathrm{pH}=8.5$. Single individuals were carefully homogenized before being loaded on the gel. Electrophoresis was carried out at room temperature at 200 volts for 18 minutes. Gel staining with the agar overlay was done at temperature of $55^{\circ} \mathrm{C}$ in the thermoincubator. Gels were scored after sufficient staining using Daphnia of known genotypes as standards.

We used as standards laboratory clones originated for D. galeata from Rimov Reservoir (Czechia) and for D. galeata $\times$ longispina from Lake Maarsseveen (The Netherlands). Four allozyme loci (sAAT: amino aspartate transferase, EC 2.6.1.1; AO: aldehyde oxidase, EC 1.2.3.1; GPI: glucose-6-phosphate isomerase, EC 5.3.1.9; PGM: phosphoglucomutase, EC 5.4.2.2) were scored. Loci were either fixed within species (differen- 
Tab. 1. Allozyme phenotypes of 50 analysed Daphnia from Lake Orta in the sample of June 2006.

\begin{tabular}{|c|c|c|c|c|c|}
\hline \multicolumn{4}{|c|}{ Locus phenotype } & \multirow{2}{*}{ Bilocus genotype code } & \multirow{2}{*}{ No of individuals } \\
\hline sAAT & $\mathrm{AO}$ & GPI & PGM & & \\
\hline $\mathrm{FF}$ & MM & MM & FM & $\mathrm{BLG}-\mathrm{A}$ & 49 \\
\hline $\mathrm{FF}$ & MM & MM & $\mathrm{FF}$ & BLG - B & 1 \\
\hline
\end{tabular}

tiation among taxa; sAAT and AO) or polymorphic (differentiation of multi-locus genotypes; GPI and PGM).

Randomly chosen Daphnia were also photographed to document Daphnia morphotypes. This enabled us to compare Daphnia from the June 2006 sample with those previously collected in May 2004.

\section{RESULTS}

The use of the 4 allozyme markers (sAAT, AO, GPI and PGM loci) allows a definition of a clonal diversity in 50 specimens of Daphnia. sAAT (synonym to GOT) was first reported by Wolf \& Mort (1986) as a diagnostic marker to discriminate between $D$. galeata and $D$. longispina. D. galeata is fixed for F (fast) alleles, whereas $D$. longispina is fixed for $\mathrm{S}$ (slow) alleles at this locus, therefore making the distinction between the two very easy. Lately, Gießler (1997) reported AO as a second diagnostic marker, as D. galeata appeared to be fixed for F (fast) alleles at this locus, while D. longispina was fixed for the S (slow) alleles. These two diagnostic markers typically enable a discrimination of the species, and of the backcrosses and second generation's hybrids as well. To solve the clonal attribution the other two additional alleles (GPI and PGM), which are polymorphic, are typically used.

The results of our analyses indicate an extreme homogeneity of the material (Tab. 1). The species diagnostic locus sAAT indicated unambiguosly the presence of D. galeata genes (all specimens were homozygous for $\mathrm{F}$ allele). The result of $\mathrm{AO}$, the second species diagnostic locus, was rather intriguing, as all specimens were homozygous for $\mathrm{M}$; this allele can be interpreted as a marker for $D$. cucullata, or as a rare allelic variant of D. longispina and of D. galeata.

The homogenous character of the analysed sample was found also on both presumed polymorphic loci GPI and PGM. GPI locus was fixed for the M allele. PGM locus showed heterozygous FM combination for all specimens except for one, which was FF homozygous. The resulting clonal structure of the sample indicates that 49/50 specimens belong to the clonal group FFMMMMFM (sAAT + AO + GPI + PGM) and only one specimen has the variant FFMMMMFF.

The homogenous character of the sample was also confirmed by the microscopic analysis of Daphnia phenotypes, which resulted very uniform (June sample) (Fig. $1 \mathrm{~d}, \mathrm{e}, \mathrm{f}$ ) and consistent with a pure D. galeata morphotype. As most individuals in the sample were subadult, we had to include 10 pre-adults in addition to the 40 ovigerous females present. However, no adult Daphnia registered and photographed before analysis resembled the $D$. longispina phenotype recorded in the past. In May 2004, both D. galeata and D. longispina were morphologically identified, in a proportion of $18 \%$ and $82 \%$ respectively. Therefore, the prevalence of $D$. galeata became clearer in 2006 , as no D. longispina could be identified even on morphological basis. The two sibling species reached very similar levels of abundance in the two different periods (2530 and 2812 ind $\mathrm{m}^{-3}$ in May 2004 and in June 2006, respectively).

\section{DISCUSSION AND CONCLUSIONS}

The presence of $D$. galeata in the nearby lakes might explain its appearance in Lake Orta, both by natural vectors or through transport associated with human activities.

The opportunity for an immigrant genotype to colonize the habitat depends on whether resources have been monopolized by resident genotypes, the intrinsic growth rate of the population, the carrying capacity and the number of colonizing propagules (De Meester et al. 2002). While the success of allochtonous species may be reduced by competition with locally adapted resident genotypes (De Meester 1996), the colonization is enhanced by the unstable conditions characterizing Lake Orta.

The results of allozyme analysis on Lake Orta Daphnia unambiguously confirm the presence of $D$. galeata genes, according to the presence of $\mathrm{F}$ allele at sAAT locus. However, they also allow a discussion on the relevance and possible interpretation of AO-based species diagnosis. In particular, the presence of allele $\mathrm{M}$ can be interpreted in different ways. It has been suggested (Gießler 1997) that this allele is indicative of the presence of Daphnia cucullata genes. According to what we know on the ecology of this species, this is not a reliable interpretation for Lake Orta because $D$. cucullata is considered a "lowland" species, typical of well buffered water bodies (Fryer 1985). In addition, according to the results by Keller et al. (2006), D. cucullata appears distributed mainly north of the Alps, therefore allowing a distinction of two biogeographic regions, a northern one in which $D$. hyalina and $D$. cucullata prevail, and a southern one, with higher temperatures and lower latitudes, in which D. galeata dominates.

According to the current taxonomical keys, the morphological diagnosis for this species is unequivocal, especially in live adults, because of the lack of an ocellus, and the emergence of the antennular aesthetes from a rounded rostrum tip.

To interpret the results of our analysis of Lake Orta Daphnia we favour the alternative interpretation of the 

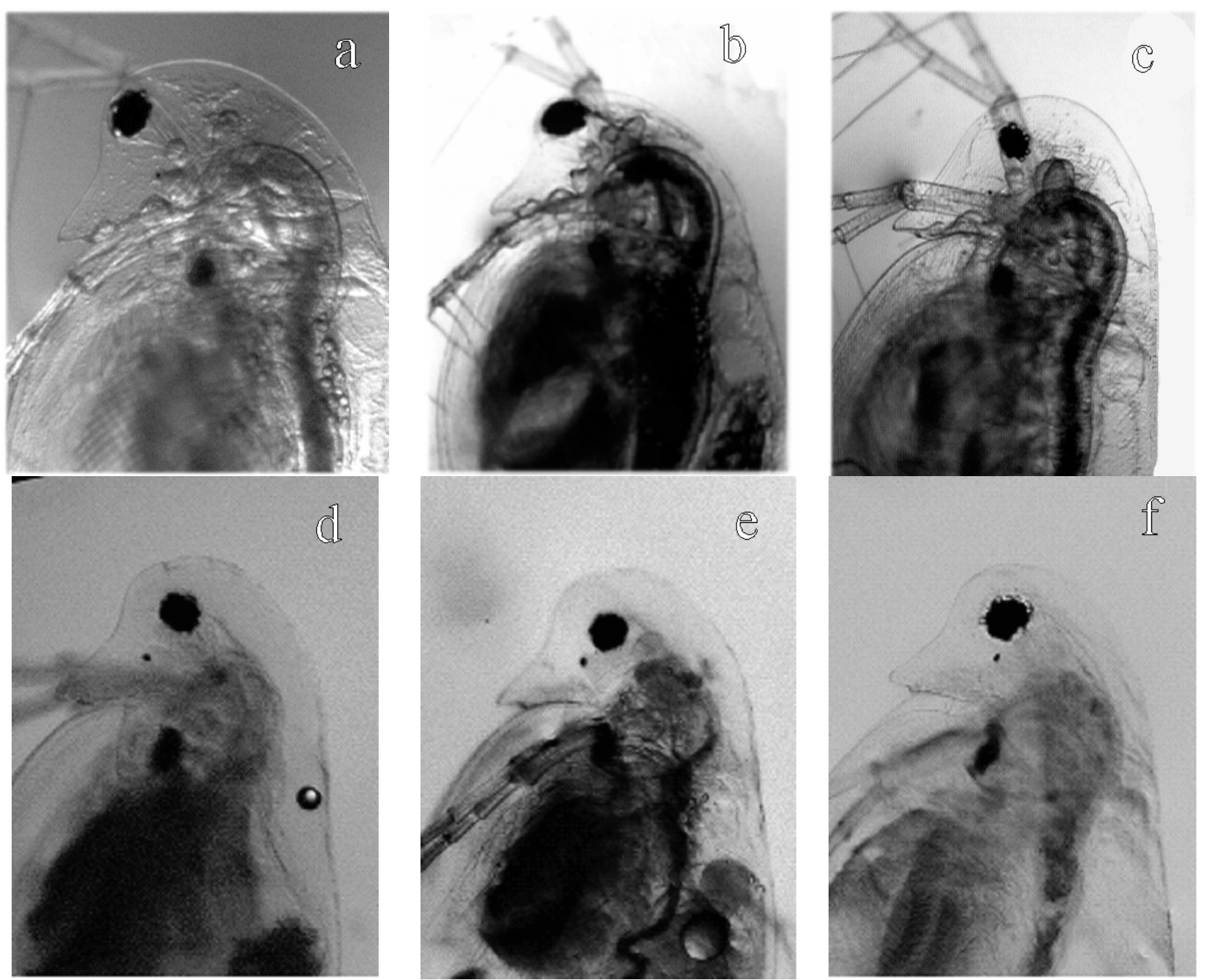

Fig. 1. Comparison of Daphnia morphotypes from May 2004 (a - c) and June $2006(\mathbf{d}-\mathbf{f})$ samples. Note the ventral position of the eye cavity in photographs a and $\mathbf{b}$, which is one of the discriminating characters for $D$. longispina.

allele at $\mathrm{AO}$ locus as a rare D. galeata variant, or as indicative of second generation's $D$. galeata $\times$ longispina hybrids. The two hypotheses are equally supported by our analysis. Our findings are in relatively good agreement with those of Keller et al. (2006) who in 2004 identified as D. galeata allozyme phenotypes about $50 \%$ of Lake Orta's Daphnia. The persistence of hybrid generations is also coherent with the Daphnia population dynamics in Lake Orta (Signorini 2006): presence of males is not a rare phenomenon, being detected in spring as well as in autumn, thus providing a good opportunity for the production of hybrids.

In nearby Lago Maggiore, despite the non-regular appearance of Daphnia males, the presence of $D$. hyalina $\times$ galeata hybrids, in addition to the two parental species, was first detected after the lake re-oligotrophication (Manca et al. 1996).

In addition, the fact that GPI locus was fixed for M allele, an uncommon situation for this relatively highly polymorphic locus, may be interpreted as resulting from a founder effect. Furthermore, the high heterozygosity level at PGM locus, with a FM combination for 49 specimens out of 50 analyzed Daphnia may be interpreted as a strong clonal selection of heterozygotes. The alternative explanation of an absence of sexual reproduction does not seem coherent with the occurrence of males we regularly observed in Lake Orta Daphnia population.

Therefore, the Lake Orta case study would confirm what was observed in other lakes of the region. As emphasized by Keller et al. (2006) habitat disturbances, such as changes in trophy, enhance hybridization. Chronic pollution and recovery may be regarded as a habitat disturbance, as well as a stress (Cattaneo et al. 1998). While in general hybrids seem to perform poorly compared with their parental species (Schwenk et al. 2001), under specific environmental conditions they may have equal or higher fitness.

Notably, the second generation hybrids cannot be distinguished from their parents on a morphological basis. 


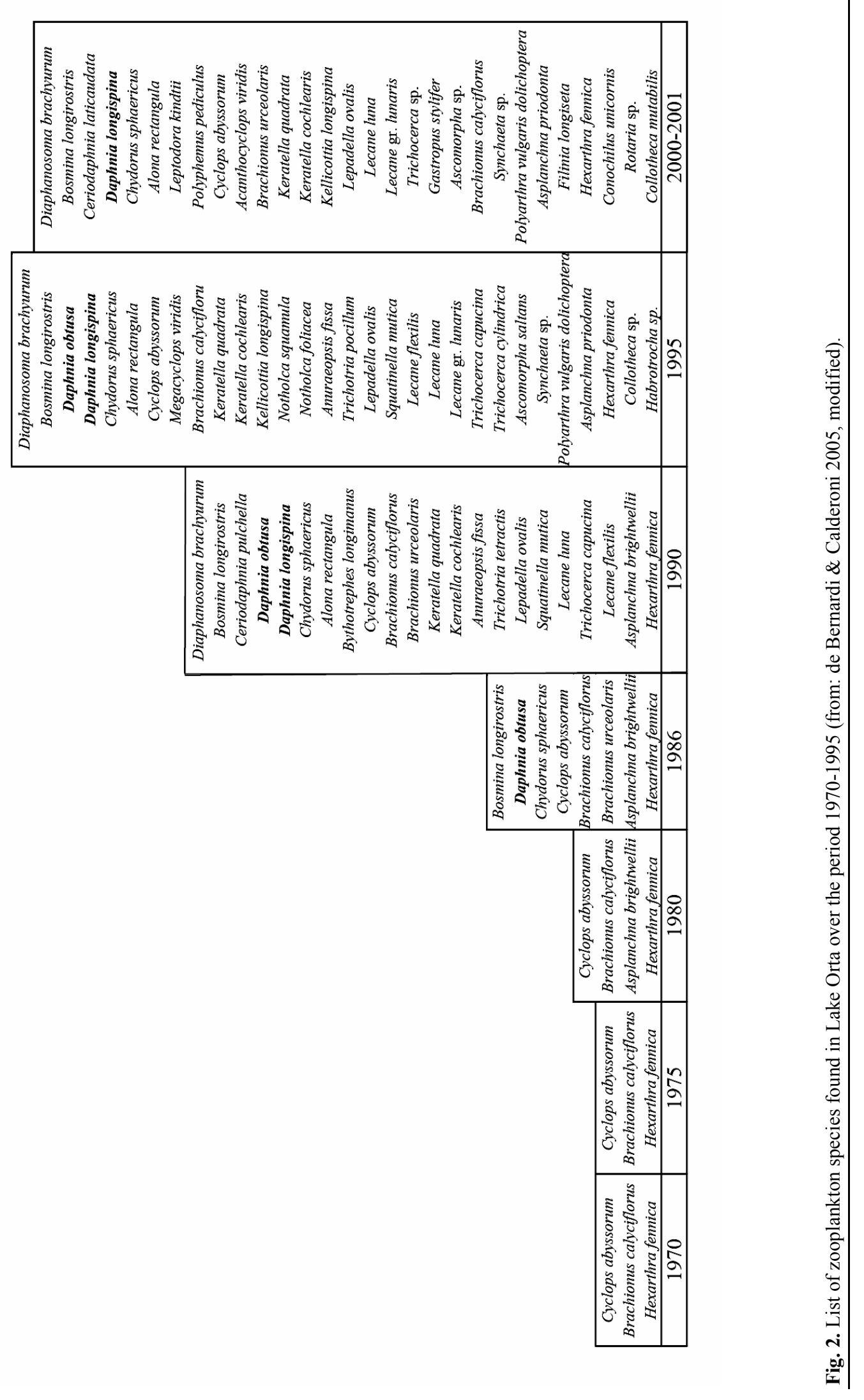


The absence of $D$. longispina-like morphotypes in the June samples may suggest a replacement of $D$. longispina by $D$. galeata in summer. However, we do not have a whole year collection of samples, as the zooplankton monitoring started again only in June 2006.

The extreme homogeneity of Daphnia for the loci GPI and PGM can be interpreted as the combination of a founder effect and a strong clonal selection.

This result is in agreement with population genetic theory, which predicts that newly established populations will exhibit founder effects, including loss of genetic variation and/or alteration of genetic structure from passing trough a bottleneck, if the founding population is small (Boileau et al. 1992; DeMelo \& Hebert 1994). The same homogeneity was found for D. obtusa by Bachiorri et al. (1991): all the 1341 D. obtusa specimens analyzed between 1987 and 1989 resulted monomorphic for 15 loci. This result supported the idea that the lake was colonized by a single clone (if not by "a single egg"!), particularly resistant to the specific environment, therefore providing an example of a founder effect with a strong clonal selection in a highly disturbed environment.

A strong clonal (or species) selection may be also deduced from the very few data on morphology we have obtained from microscopic analysis (cf Fig. 1).

Finally, the presence of D. galeata in Lake Orta provides an additional evidence for the improvement of environmental conditions which started from the eighties with an increasing complexity of the zooplankton community (Fig. 2).

The present manuscript is a preliminary note about the presence of D. galeata in Lake Orta. Further studies are needed for better understanding its appearance, its future development and its implication for the structure and functioning of the lake food web.

\section{ACKNOWLEDGEMENTS}

We thank Andrea Ferrari, CNR-ISE for technical help in collecting zooplankton samples. Dr Riccardo de Bernardi (CNR-ISE), Prof. A. Cattaneo (Universitè de Montréal, Québec) and Z. Brandl (University of South Bohemia, České Budějovice, Czechia) for critical suggestions and the peer revision of the original manuscript.

\section{REFERENCES}

Bachiorri, A., V. Rossi \& P. Menozzi. 1991. Differences in demographic parameters among electrophoretric clones of Daphnia obtusa Kurz (Crustacea, Cladocera). Hydrobiologia, 225: 263-268.

Bachiorri, A., V. Rossi, C. Bonacina \& P. Menozzi. 1989. Enzymatic variability of a colonizing population of Daphnia obtusa Kurz (Crustacea, Cladocera) in Lake Orta (Italy). Verh. int. Ver. Limnol., 24(5): 2813-2815.

Benzie, J.A.H. 2005. The genus Daphnia (including Daphniopsis) (Anomopoda: Daphniidae). In: Guides to identification of the microinvertebrates of the continental waters of the world. Backhuys Publishers, Leiden: $376 \mathrm{pp}$.
Boileau, M.G., P.D.N. Hebert \& S.S. Schwartz. 1992. Nonequilibrium gene frequency divergence: persistent founder effects in natural populations. J. Evol. Biol., 5: 25-39.

Bonacina, C. 2001. Lake Orta: the undermining of an ecosystem. J. Limnol., 60(1): 53-59.

Bonacina, C., R. de Bernardi \& M.I. Taticchi. 1994. Types of response to environmental-changes in cladoceran populations. Boll. it. Zool., 61(4): 385-393.

Bonacina, C., G. Bonomi, L. Barbanti, R. Mosello \& D. Ruggiu. 1988a. Recovery of an industrially acidified, ammonium and heavy metals polluted lake (Lake Orta, N. Italy), due to the adoption of treatment plants. Verh. int. Ver. Limnol., 23: 535-544.

Bonacina, C., G. Bonomi, L. Barbanti, R. Mosello, D. Ruggiu \& G. Tartari. 1988b. Lake Orta (N. Italy): recovery after the adoption of restoration plans. In: N.W. Schmidtke (Ed.), Toxic Contamination in Large Lakes. Vol. $2^{\circ}$ : Impact of Toxic Contaminants on Fisheries Management. Proc. World Conference on Large Lakes, Mackinac Island, Mich., May 18-21, 1986: 101-130.

Bonacina, C., W. Ambrosetti, L. Barbanti, G. Bonomi, A. Calderoni, R. Mosello, D. Ruggiu, A. Ferrari, V. Libera, P. Panzani Guida, B. Sulis, A. Pranzo \& G. Tartari. 1986. L'evoluzione pluriennale delle caratteristiche chimiche e delle strutture biotiche del Lago d'Orta, come conseguenza degli interventi di risanamento. Documenta Ist. ital. Idrobiol., 17: 64-76.

Calderoni, A., R. Mosello, A. Quirci \& R. de Bernardi. 1990a. Recovery of Lake Orta by liming. Proc. VII Int. Lime Congr. Rome, September, 13-14, 1990: 157-171.

Calderoni, A., R. de Bernardi \& R. Mosello. 1990b. Proposta di risanamento del Lago d'Orta tramite liming. In: C. Bonacina, A. Calderoni \& R. de Bernardi (Eds), Ricerche limnologiche sul Lago d'Orta finalizzate al suo risanamento. Documenta Ist. ital. Idrobiol., 28: 117-131.

Calderoni, A., R. Mosello \& A. Quirci. 1991. Chemical response of Lake Orta (Northern Italy) to liming. Arch. Hydrobiol., 122: 421-439.

Calderoni, A., R. Mosello \& D. Ruggiu. 1992. Sixty years of limnology on Lago d'Orta: a case history of recovery from heavy pollution. In: P. Guilizzoni, G. Tartari \& G. Giussani (Eds), Limnology in Italy. Mem. Ist. ital. Idrobiol., 50: 201-224.

Cattaneo, A., A. Asioli, P. Comoli \& M. Manca. 1998. Organisms' response in a chronically polluted lake supports hypothesized link between stress and size. Limnol. Oceanogr., 43(8): 1938-1943.

de Bernardi, R. \& C. Calderoni. (2006). Problemi di qualità nelle acque lacustri italiane con particolare riferimento all'analisi a lungo termine di alcune problematiche ambientali nei grandi laghi subalpini. Giornata dell'Acqua 2005. Accademia dei Lincei. Roma, 22 Marzo 2005: (in press).

De Meester, L. 1996. Local genetic differentiation and adaptation in freshwater zooplankton populations: patterns and processes. Ecoscience, 3: 385-399.

De Meester, L., A. Gómez, B. Okamura \& K. Schwenk. 2002. The monopolization hypothesis and the dispersal-gene flow paradox in aquatic organisms. Acta Oecologica, 23: 121-135.

DeMelo, R. \& P.D.N. Hebert. 1994. Founder effects and geographical variation in the invading cladoceran Bosmina (Eubosmina) coregoni Baird 1857 in North America. Heredity, 73: 490-499.

Flößner, D. 2000. Die Haplopoda und Cladocera (ohne Bosminidae) Mitteleuropas. Backhuys Publishers, Leiden: 428 $\mathrm{pp}$.

Fryer, G. 1985. The ecology and the distribution of the genus Daphnia (Crustacea: Cladocera) in restricted areas: the pattern in Yorkshire. Journal of Natural History, 19: 97128. 
Gießler, S. 1997. Analysis of reticulate relationships within the Daphnia longispina species complex. Allozyme phenotype and morphology. J. Evol. Biol.,10: 87-105.

Hebert, P.D.N. \& M.J. Beaton. 1989. Methodologies for allozyme analysis using cellulose acetate electrophoresis. Helena Laboratories, Beaumont, Texas.

Hebert, P.D.N., S.S. Schwartz \& J. Hrbáček. 1989. Patterns of genotypic diversity in Czechoslovakian Daphnia. Heredity, 62: 207-216.

Hrbáček, J. 1987. Systematics and biogeography of Daphnia species in the northern temperate regions. In: R.H. Peters $\&$ R. de Bernardi (Eds), Daphnia. Mem. Ist. ital. Idrobiol.: 37-76.

Keller, B., J. Wolinska, M. Manca, \& P. Spaak. (2006). Spatial environmental and anthropogenic effect on the taxa composition. Ecology: (in press).

Manca, M., M.C. Canale, M. Beltrami \& R. de Bernardi. 1996. Indagini sullo zooplancton. In: Istituto Italiano di Idrobiologia-CNR (Ed.), Ricerche sull'evoluzione del Lago Maggiore. Aspetti Limnologici. Programma quinquennale 1993-1997. Campagna 1995 con sintesi degli anni 1993 e 1994. Commissione Internazionale per la protezione delle acque italo-svizzere (Ed.): 59-68.

Margaritora, F. 1983. Cladoceri (Crustacea: Cladocera). In: S. Ruffo (Coord.), Guide per il riconoscimento delle specie animali delle acque interne italiane. Collana del progetto finalizzato Promozione della qualità dell'ambiente AQ/1/97. Consiglio Nazionale delle Ricerche: 169 pp.

Monti, R. 1929. Limnologia comparata dei laghi insubrici. Verh. int. Ver. Limnol., 4: 462-497.

Monti, R. 1930. La graduale estinzione della vita nel limnobio del Lago d'Orta. Rend. Ist. Lomb. Sc. Lett., 63: 3-22.
Mosello, R., R. Baudo \& G.A. Tartari. 1986. Metal concentrations in a highly acidic lake: L. Orta (Northern Italy). Mem. Ist. ital. Idrobiol., 44: 73-96.

Pavesi, P. 1879. Ulteriori studi sulla fauna pelagica dei laghi italiani. Rend. R. Ist. Lomb. Sc. Lett., 12: 688-707.

Petrusek, A., F. Bastiansen \& K. Schwenk. 2005. European Daphnia Species (EDS): a digital catalogue and identification key of Daphnia from Europe and the Mediterranean. In: Abstract Book of VIIth International Symposium on Cladocera, September 3 - 9, 2005 Herzberg Switzerland: 36.

Schwenk, K. \& P. Spaak. 1995. Evolutionary and ecological consequences of interspecific hybridization in cladocerans. Experientia, 51: 465-481.

Schwenk, K., M. Bijl \& S.B.J. Menken. 2001. Experimental interspecific hybridization in Daphnia. Hydrobiologia, 442: 67-73.

Signorini, C. 2006. Lo zooplancton del Lago d'Orta nel 2001: condizioni attuali e confronto con la situazione precedente. Tesi di laurea Università degli Studi di Milano: 63 $\mathrm{pp}$.

Spaak, P. 1996. Temporal changes in the genetic structure of the Daphnia species complex in Tjeukemeer, with evidence for backcrossing. Heredity, 76: 539-548.

Wolf, H.G. \& M.A. Mort. 1986. Inter-specific hybridization underlies phenotypic variability in Daphnia populations. Oecologia, 68: 507-511.

Wolinska, J., B. Keller, M. Manca \& P. Spaak. (2006). Parasite survey of a Daphnia hybrid complex: host-specifity and environment determine infection. J. Animal. Ecol.: (in press). 